\title{
Subcutaneous fat necrosis of the newborn: clinical manifestations in two cases*
}

\author{
Necrose gordurosa subcutânea do recém-nascido: manifestações \\ clínicas de dois casos
}

\author{
Milena Pires de Campos Luciano Gomes ${ }^{1}$ \\ Milvia Maria Simões da Silva Enokihara ${ }^{3}$
}

\author{
Adriana Maria Porro ${ }^{2}$ \\ Marcos César Floriano ${ }^{4}$
}

DOI: http://dx.doi.org/10.1590/abd1806-4841.20132229

\begin{abstract}
Subcutaneous fat necrosis of the newborn is an unusual form of panniculitis, with few cases described in medical literature. The disease affects newborns at term or post-term, with normal general health. We describe two cases of newborns affected by the disease. One of them already had lesions since birth. Also, we discuss the use of puncture for diagnostic assistance.
\end{abstract}

Keywords: Biopsy, Fine-Needle; Fat Necrosis; Infant, Newborn

Resumo: A Necrose Gordurosa Subcutânea do Recém-Nascido é uma paniculite incomum com poucos casos descritos na literatura médica. A doença acomete recém-nascidos a termo ou pós-termo, com saúde geral normal. Relatamos dois casos de recém-nascidos acometidos pela doença. Um deles já apresentava lesões ao nascer. Também discutimos o uso da punção para auxílio diagnóstico.

Palavras-chave: Biópsia por agulha fina; necrose gordurosa; Recém-nascido

\section{INTRODUCTION}

Subcutaneous fat necrosis of the newborn is an uncommon lobular form of panniculitis, characterized by single or multiple erythematous-violaceous plaques and nodules, which can evolve into calcification. They are found especially on the shoulders, buttocks, backs and faces of newborns at term or postterm, with normal general health. It can occur from birth, up until the first six weeks of life. ${ }^{1}$

We discuss two cases of newborns at term who developed painful subcutaneous nodules associated with breathing difficulties at birth. One presented lesions at birth. In both cases, lesions improved, with few related complications.

\section{REPORT ON CASES}

Case 1: male patient, born at term by cesarean, with two rounds of umbilical cord around his neck. Weight at birth: 3480g. Shortly after the birth, he experienced respiratory discomfort with signs of sepsis, affecting the pulmonary region. He was given vancomycin and cefepime for 21 days, which treated the infection. At birth, he presented hardened, erythematous, edematous lesions on the back and upper limbs. Subcutaneous nodules, with fluctuation in size, emerged in these regions within a matter of days. After antibiotic therapy was conducted, the inflammation improved, though hardened nodules remained in the upper-back region, the distal extensor

Received on 25.10.2012.

Approved by the Advisory Board and accepted for publication on 27.11.2012.

* Study carried out in the department of dermatology of the Paulista Medical School- Federal University of São Paulo (EPM-UNIFESP) - São Paulo (SP), Brazil. Conflict of interest: None

Financial funding: None

Dermatologist - Postgraduate student in advanced dermatology at the Paulista Medical School - Federal University of São Paulo (EPM-UNIFESP) - São Paulo (SP), Brazil.

PhD in Medicine from the Paulista Medical School - Federal University of São Paulo (EPM-UNIFESP) - Adjunct Professor of the dermatology department at the Paulista Medical School- Federal University of São Paulo (EPM-UNIFESP) - São Paulo (SP), Brazil.

PhD from the pathology department of the Paulista Medical School- Federal University of São Paulo (EPM-UNIFESP)- Qualified dermapathologist, at the pathology and dermatology departments of the Paulista Medical School- Federal University of São Paulo (EPM-UNIFESP) - São Paulo (SP), Brazil.

4 Master's in Medicine from the Paulista Medical School- Federal University of São Paulo (EPM-UNIFESP)- assistant doctor in the department of dermatology of the Paulista Medical School- Federal University of São Paulo (EPM-UNIFESP) - São Paulo (SP), Brazil. 
surface of the arms and masseter region, bilaterally. He presented a slight increase in serum calcium levels, which did not require any specific measures. A biopsy of the lesion on the right arm was carried out, showing organized fat necrosis. After four months of evolution, he presented residual calcified nodules on the arms and remained with atrophy in the affected regions (Figure 1).

Case 2: female patient, born at term by cesarean. Weight at birth: 3240g. Soon after the birth, cardiorespiratory reanimation and orotracheal intubation were carried out, since there had been fetal suffering due to the presence of meconium in the amniotic fluid. She evolved with thrombosis of the caval, left renal and iliac, veins. She was treated with heparin and enoxaparin, to positive effect, but experienced failure of the left kidney. After one month, she presented painful subcutaneous nodules with erythema on the surface, on the left buttock, left mandibular region and arms (Figure 2). A fine-needle aspiration puncture was performed on one of the nodules on the left buttock, revealing a strange body reaction (Figures 3 and 4), as well as a biopsy of a lesion on the left buttock, which showed fat necrosis (Figure 5). There were no changes in serum calcium levels, like in the first case. She recovered completely from the lesions in the fourth month.

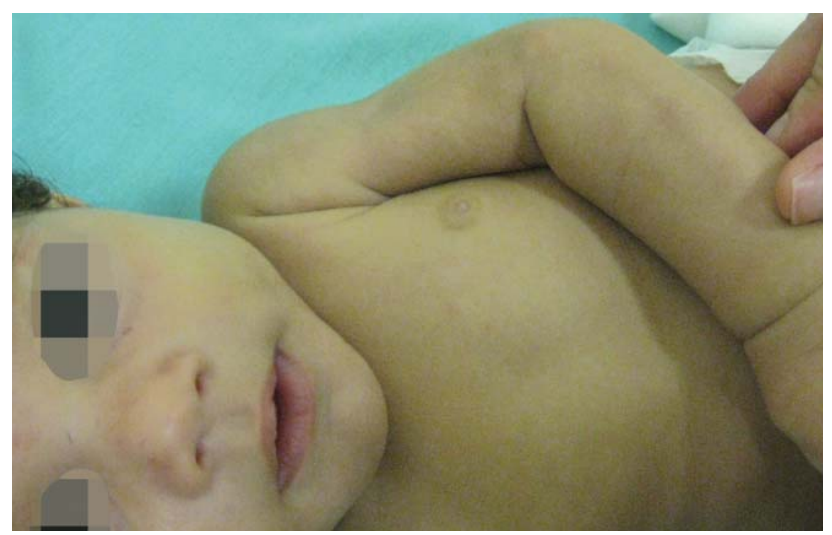

Figure 1: Case 1. Areas of atrophy on the left arm and left masseter region. Hardened nodule in the distal region of the left arm. Residual lesions.

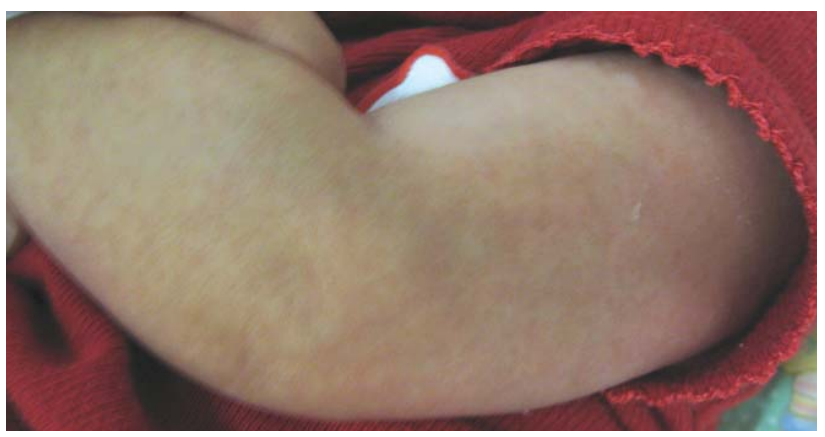

FIGURE 2: Case 2. Edema and erythema on the left arm

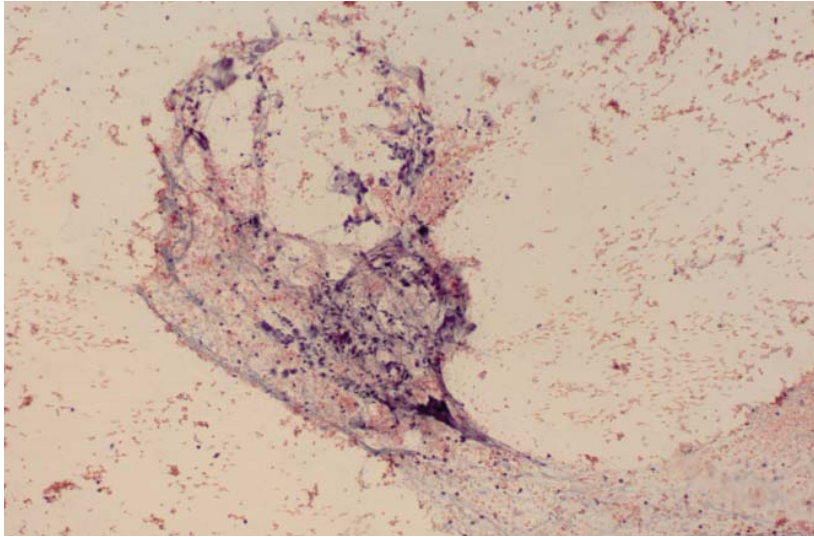

Figure 3: Case 2 - Fine-needle aspiration puncture (FNAP). FNAP product stained by the papinicolaou method. A close-knit grouping of histiocytes, lymphocytes and adipose cells, was noted (100x)

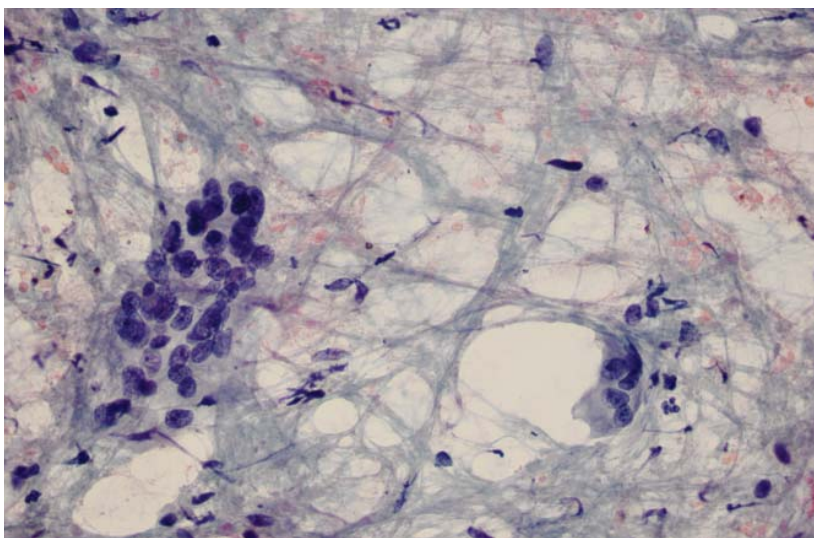

FIGURE 4: Case 2 - Fine-needle aspiration puncture. FNAP presenting, in detail, a grouping of histiocytic cells to the left and an adipocyte containing one giant multinucleated cell to the right (Papanicolaou 400x)

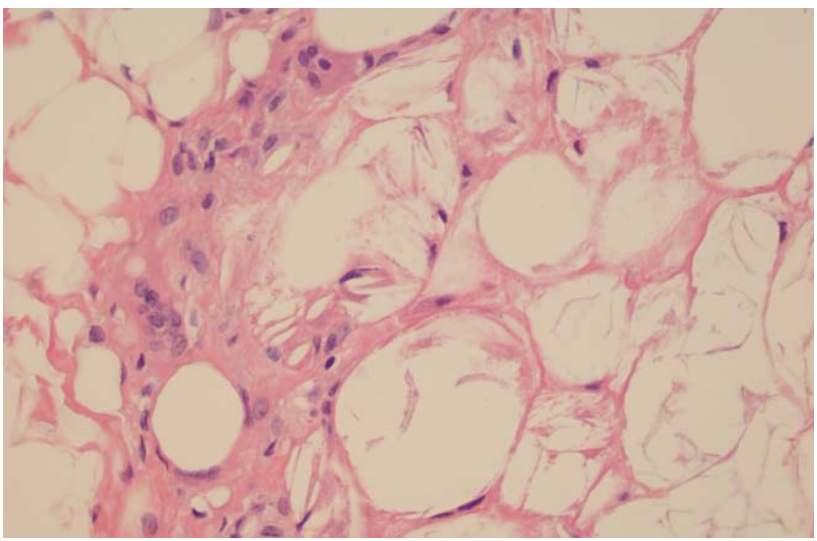

FIGURE 5: Case 2 - Histological exam. Subcutaneous adipose tissue reveals, to the left, a giant strange body multinucleated cell. To the right, necrotic adipocytes (without nucleus) can be observed, as well as cholesterol crystals in the center of the photo (needle-shaped fissures in radial arrangement) (HE 400x) 


\section{DISCUSSION}

Subcutaneous fat necrosis of the newborn is an unusual form of panniculitis. Few cases have been described in medical literature. The newborns affected are born at term or post-term, with normal general health, though there have been cases of pre-term newborns being affected. ${ }^{1,2}$ It generally occurs within the first six weeks of life, and no cases of lesions present at birth were found in the literature consulted.

It is linked to certain predisposing factors, such as preeclampsia, gestational diabetes, use of calciumchannel blockers or cocaine by the mother, meconium aspiration, primary alteration of brown fat, umbilical cord prolapse, Rh incompatibility, and, more commonly, hypothermia, obstetric trauma, localized tissue hypoxia and neonatal asphyxia. ${ }^{1,3,4}$ This last factor featured in the two cases reported here, while primary alteration of brown fat could be linked to case 1, in which the patient already presented lesions at birth. Mahé et al linked family and personal risk factors for dyslipidemia and thrombosis, with subcutaneous fat necrosis of the newborn. Thrombosis was observed in case 2, as the patient presented thrombosis of the caval, left renal and iliac veins. ${ }^{4}$ Recently, cases of subcutaneous fat necrosis have been described in newborns submitted to moderate therapeutic hypothermia for hypoxic-ischemic encephalopathy. ${ }^{5}$

The main manifestations are erythematous-violaceous plaques and nodules, single or multiple, which can evolve into calcification, and are found especially on the shoulders, buttocks, back and face. Greater extent of the disease could be linked to the occurrence of neonatal asphyxia. ${ }^{3}$ After recovering from the condition, most babies remain with cutaneous atrophy in the regions of the lesions, as observed in case $1 .^{4}$

A differential diagnosis should be carried out for neonatal sclerema, a form of hardened edema, which generally begins in the lower limbs and grows progressively, occurring in premature babies with an underlying disease. ${ }^{1}$ Burden et al advance that these two diagnoses are spectrums of severity of the same disease. ${ }^{3}$
The histopathological exam for subcutaneous fat necrosis of the newborn shows lobular panniculitis with fat necrosis, strange body inflammatory granulomas, and fibrosis. There is a high number of giant multinucleated and histiocytic cells, as well as needleshaped birefringent crystals and fissures, with radial arrangements inside the adipocytes. ${ }^{1}$

Fine-needle aspiration puncture is an option for diagnosis, making it possible to observe changes that are similar to those seen in the histopathological exam. ${ }^{6}$ Parvathidevi et al argue that this should be the exam of choice, given that it is less invasive than a biopsy. ${ }^{7}$ In case 2, this exam was performed, showing a strange body reaction, a change that assist in diagnosis.

Some possible complications include: fat liquefaction and fluctuation, transitory thrombocytopenia, hypoglycemia, hypertriglyceridemia and hypercalcemia. $^{8}$

Hypercalcemia is the most significant complication and it occurs in $25 \%$ of cases, usually when lesions start to regress. However, Bonnemains et al reported symptomatic hypercalcemia beginning before the emergence of cutaneous lesions. ${ }^{9}$ In gener$\mathrm{al}$, this occurs when the disease is more severe and, in all such babies, the midsection is affected.

Hypercalcemia symptoms are: lethargy, irritability, hypotonia, vomiting, polyuria, polydipsia, dehydration and constipation. ${ }^{8}$

Tran and Sheth suggest total and ionized calcium as weekly or biweekly measures up until the age of 6 months. ${ }^{8}$

Hypercalcemia can lead to calcification of the kidneys, falx cerebri, skin, myocardium and gastric mucosa. ${ }^{8}$

Treatment for subcutaneous fat necrosis of the newborn is not necessary because the condition is auto-limited. When there is hypercalcemia, treatment is typically carried out using furosemide, intravenous hydration with $0.9 \%$ saline solution and a diet with low levels of calcium and vitamin D. In refractory cases, corticosteroids can be used. ${ }^{1}$ Lombardi et al obtained positive results using pamidronate in a case that did not respond to these treatments. ${ }^{10} \square$ 


\section{REFERENCES}

1. Paige DG, Gennery AR, Cant AJ. The Neonate. In: Burns T, Breathnach S, Cox N, Griffiths C, editors. Rook's textbook of dermatology. 8th ed. Massachusetts: Blackwell Publishing; 2010. p.590-2.

2. Oliveira ACS, Selores M, Pereira O. Fat necrosis of the newborn--report on two cases. An Bras Dermatol 2011;86:S114-7.

3. Burden AD, Krafchik BR. Subcutaneous fat necrosis of the newborn: a review of 11 cases. Pediatr Dermatol. 1999;16:384-7.

4. Mahé E, Girszyn N, Hadj-Rabia S, Bodemer C, Hamel-Teillac D, De Prost Y. Subcutaneous fat necrosis of the newborn: a systematic evaluation of risk factors, clinical manifestations, complications and outcome of 16 children. $\mathrm{Br} \mathrm{J}$ Dermatol. 2007;156:709-15.

5. Strohm B, Hobson A, Brocklehurst P, Edwards AD, Azzopardi D; UK TOBY Cooling Register. Subcutaneous fat necrosis after moderate therapeutic hypothermia in neonates. Pediatrics. 2011;128:e450-2.

6. Gupta RK, Naran S, Selby RE. Fine needle aspiration cytodiagnosis of subcutaneous fat necrosis of newborn. A case report. Acta Cytol. 1995;39:759-61.

7. Parvathidevi GK, Vijayashankar MR, Belagavi CS, Deepak, Vijaya, Narendra G, et al. Cytological diagnosis of subcutaneous fat necrosis of newborn: a case report. Dermatol Online J. 2005;11:20.

8. Tran JT, Sheth AP. Complications of subcutaneous fat necrosis of the newborn: a case report an review of the literature. Pediatr Dermatol. 2003;20:257-61.

9. Bonnemains L, Rouleau S, Sing G, Bouderlique C, Coutant R. Severe neonatal hypercalcemia caused by subcutaneous fat necrosis without any apparent cutaneous lesion. Eur J Pediatr. 2008;167:1459-61.

10. Lombardi G, Cabano R, Bollani L, Del Forno C, Stronati M. Effectiveness of pamidronate in severe neonatal hypercalcemia caused by subcutaneous fat necrosis: a case report. Eur J Pediatr. 2009;168:625-7.

\author{
MAILING ADDRESS: \\ Milena Pires de Campos Luciano Gomes \\ Rua Borges Lagoa, 508 - Vila Clementino \\ 04038-001 - São Paulo - SP \\ Brazil \\ Email:milena_epm@yahoo.com.br
}

How to cite this article: Gomes MPCL, Porro AM, Enokihara MMSS, Floriano MC. Subcutaneous fat necrosis of the newborn: clinical manifestations in two cases. An Bras Dermatol. 2013;88(6 Suppl 1):S154-7. 